Article

\title{
Enhanced Aromatic Profile and Functionality of Cheese Whey Beverages by Incorporation of Probiotic Cells Immobilized on Pistacia terebinthus Resin
}

\author{
Vasiliki Schoina ${ }^{1}$, Antonia Terpou $^{1, *} \mathbb{\infty}$, Aikaterini Papadaki ${ }^{2} \mathbb{D}$, Loulouda Bosnea ${ }^{3, *}$, \\ Nikolaos Kopsahelis $^{2}$ D and Maria Kanellaki ${ }^{1}$ \\ 1 Food Biotechnology Group, Department of Chemistry, University of Patras, GR-26500 Patras, Greece; \\ schoina_vasiliki@hotmail.com (V.S.); m.kanellaki@upatras.gr (M.K.) \\ 2 Department of Food Science and Technology, Ionian University, 28100 Kefalonia, Greece; \\ kpapadaki@aua.gr (A.P.); kopsahelis@upatras.gr (N.K.) \\ 3 Hellenic Agricultural Organization DEMETER, Dairy Research Institute, 45221 Ioannina, Greece \\ * Correspondence: aterpou@upatras.gr (A.T.); louloudabosnea@gmail.com (L.B.); Tel.: +032610997123 (A.T.); \\ +0302651094781 (L.B.)
}

Received: 4 December 2019; Accepted: 20 December 2019; Published: 22 December 2019

\begin{abstract}
In the present study, cheese whey was utilized for the development of a novel functional beverage, using Lactobacillus casei ATCC 393 probiotic cells immobilized on Pistacia terebinthus resin (pissa Paphos). Evaluation of shelf life of the produced beverages showed that spoilage microorganisms were not observed in beverages containing $P$. terebinthus resin. Terpenes' rich content might have contributed to the antimicrobial activity of the produced beverages; however, no significant effect on the viability of the immobilized probiotic cells was obtained. Whey beverages containing the immobilized biocatalyst retained a high viability $\left(>1 \times 10^{6} \mathrm{CFU} / \mathrm{g}\right)$ of probiotic cells during a storage period of 30 days at $4{ }^{\circ} \mathrm{C}$. The superiority of whey beverages containing the immobilized biocatalyst was also highlighted by GC-MS analysis, while the enhanced aromatic profile, which was mostly attributed to the higher concentration of terpenes, was also detected during the sensory evaluation performed. Conclusively, this study indicated the high commercialization potential of these novel functional whey beverages, within the frame of a sustainable dairy waste valorization approach. To the best of our knowledge, this is the first food-oriented approach within the guidelines of the circular economy reported in the literature, using the autochthonous Pistacia terebinthus resin for the production of functional whey beverages.
\end{abstract}

Keywords: functional whey beverage; cheese whey; Pistacia terebinthus resin; probiotics; immobilization; terpenes

\section{Introduction}

Cheese whey is the main liquid by-product of the dairy industry, which contains many valuable constituents; while its approximate amount during cheese production may range between 8 and 9 L per $\mathrm{kg}$ of produced cheese, depending on cheese yield or type of processed milk [1,2]., Cheese whey may be discarded as a waste to the environment, representing an important polluting problem due to its high organic load [3]. The applications of cheese whey valorization are rather limited; concerning the industrial relevance, only a small portion of whey by-product is used for animal feed or food applications, while the rest is discarded to the environment [4]. The disposal of these effluents without an appropriate pretreatment can pose serious environmental hazards [2]. On the other hand, recent reports have revealed the importance of cheese whey composition and proposed alternative valorization options, aiming to establish a sound basis and take advantage of its high nutritional and 
functional value content $[1,5]$. Cheese whey retains approximately $50 \%-55 \%$ of milk nutrients, and thus it can be used as a potential resource for various value-added products [4]. More specifically, cheese whey could be a valuable food itself, as it is a source of high-quality proteins, minerals, vitamins, and lactose [5,6]; however, cheese whey is not preferred by consumers in its current form, which is mostly due to its unpleasant flavor. The latest research efforts target its transformation into a wide range of valuable products through the application of different technological processes [7]. Specifically, the valorization of cheese whey has been proposed as a substrate for food production, such as whey cheeses and whey-based beverages, or as a potential feedstock for the production of valuable compounds through fermentation processes, such as probiotic starter cultures, baker's yeast, single cell protein, and biofuel production [5].

More specifically, a constantly increasing interest has been noted lately, regarding whey/dairy beverages and consumers' preference [8-10]. Whey-based beverages are an excellent way to reuse the liquid whey produced from cheese manufacturing [5]. The term 'whey beverage' has been used to describe a drinkable product based on liquid cheese whey by-product as the main or as the most significant component [11]. Non-alcoholic whey beverages include a wide range of products manufactured by mixing native sweet, acid whey, or diluted whey with different additives such as fruits, fruit juices, crops and crop by-products, prebiotics, chocolate, and other aromatic agents [11-15]. This kind of ready-to-drink beverage is very common and popular among consumers and can lead to profitable and sustainable processes, especially when incorporated together with other functional ingredients [5,15].

Approaches that can increase the resistance and viability of sensitive probiotic bacteria against adverse conditions have been already proposed, including the appropriate selection of acid and bile resistant strains, the addition of prebiotics, stress adaptation, cell immobilization, and drying (freeze-drying, spray-drying) [16,17]. Among them, immobilization has been previously reported as a technology that can provide protection to these sensitive cultures throughout manufacture, storage, freezing conditions, and during transit through the gastrointestinal tract [18-20].

In previous studies, resins from different tree species have been successfully employed for the encapsulation of lactobacilli and yeast cells [21-25]. The most popular resins originate from Pistacia plants (Pistacia lentiscus, Pistacia terebinthus), which are mostly native to the Mediterranean region [26]. The immobilization of probiotics on resins provides protection to the bacterial cells, especially when they are exposed to stressful environmental conditions such as low $\mathrm{pH}$, gastrointestinal conditions, high salinity, and heat treatment [21-23]. According to a recent study, the resin deriving from Pistacia lentiscus was used as a microencapsulating and matrix-forming material for sustained drug release [27]. In addition, a more recent study revealed that Pistacia lentiscus mastic extract shows no toxic effects in Caco-2 cells, while in parallel, it may improve the intestinal barrier function [28]. Caco-2 cells are widely used to study human absorption and transport processes, as they are human adenocarcinoma cells. Likewise, mastic gum has been lately assigned as a traditional herbal medicine for oral and cutaneous use for the treatment of mild dyspeptic disorders, minor inflammations of the skin, and as an aid in healing of minor wounds, by the European Medicines Agency (EMA) [29], whereas several studies reported that it is safe and well-tolerated by humans, contributing to the smooth operation of the gastrointestinal system $[27,30,31]$. Moreover, other related species such as P. atlantica, P. palaestina, and $P$. terebinthus produce a resin similar to mastic [32]. All these resins have been widely studied for their health effects in several food applications, such as bakery products, chewing gums, liquor, flavored wines, flavored water, and filter coffee [32]. Resins in general are suitable matrix materials for probiotic bacteria immobilization, providing in parallel health benefits to the consumers.

The resin deriving from Pistacia terebinthus, which is commonly known as pissa Paphos, is widely distributed in most coastal and inner regions of Cyprus. Pissa Paphos has a crystalline form and is secreted from the thorium tree trunk, where it appears as a tear in the engraved points of the tree. Pissa Paphos has recently been reported to contain specific components, such as terpenoids, which have been associated with anti-inflammatory and antimicrobial effects. Moreover, natural phenols and 
flavonoids have been also related to potential antioxidant and anticancer activities [33]. Still, Pissa Paphos has not been widely investigated as immobilization support.

The aim of the present work was to take advantage of the compositional and textural properties of Pissa Paphos for the production of a novel whey-based functional beverage. In the frame of that, $L$. casei ATCC 393 probiotic cells have been immobilized on Pissa Paphos, freeze-dried, and subsequently used in cheese whey fermentations. The obtained results pointed out the antimicrobial and biopreservative synergistic action of the immobilized biocatalyst, together with the enhanced aromatic character of the produced beverages. Likewise, the present study proposes an innovative and sustainable cheese whey valorization process toward the production of functional beverages.

\section{Materials and Methods}

\subsection{Immobilized Probiotic Biocatalyst}

The Gram-positive probiotic bacterial strain Lactobacillus casei ATCC 393 (DSMZ, Braunschweig, Germany) was selected for the production of the immobilized biocatalyst. L. casei biomass was grown under anaerobic conditions at $37^{\circ} \mathrm{C}$ for $48 \mathrm{~h}$ in MRS broth (LabM, Heywood, UK). Wet biomass was harvested by centrifugation (Sigma 3K12, Bioblock Scientific, Osterode am Harz, Germany) at $5000 \mathrm{rpm}$ for $10 \mathrm{~min}$ at $25^{\circ} \mathrm{C}$. The harvested biomass of L. casei ATCC 393 was introduced in MRS broth along with freeze-dried particles of Pistacia terebinthus resin (Pissa Paphos), which were priory sterilized and remained at $37^{\circ} \mathrm{C}$ for $48 \mathrm{~h}$ [22]. When the medium was exhausted (sugar content $<0.1 \%$ ), the fermented liquid was decanted, and the probiotic biocatalyst was washed twice with sterile $1 / 4$ strength Ringer's solution (LabM) for the removal of free cells [22]. The probiotic immobilized biocatalyst was frozen without cryoprotectants at $-45^{\circ} \mathrm{C}$ (cooling rate $5^{\circ} \mathrm{C} / \mathrm{min}$ ), and freeze-dried for $48-72 \mathrm{~h}$ at $-45^{\circ} \mathrm{C}$ and $5 \times 10^{-3}$ mbar in a Freeze-Drying System, Freezone 4.5 (Labconco, Kansas City, MI, USA). All media were autoclaved at $120^{\circ} \mathrm{C}$ at $1-1.5 \mathrm{~atm}$ for $15 \mathrm{~min}$ prior to use.

\subsection{Functional Whey Beverages Production}

Deproteinized cheese whey with the following composition $(w / v):<0.1 \%$ fat, $0.4 \%$ total protein, $4.7 \%$ total carbohydrates, and $\mathrm{pH} 6.4$, was supplied by a local cheese factory (A.VI.GAL SA-Achaia milk industry) as an industrial by-product of feta cheese production (after Myzithra cheese production) and used as a base material to produce functional whey beverages. Initially, cheese whey was diluted with tap water $(1: 1, v / v)$, pasteurized at $65^{\circ} \mathrm{C}$ for $30 \mathrm{~min}$, and then remained at room temperature to cool down. Whey was filtered, and its $\mathrm{pH}$ value was adjusted to 3.9 by the addition of $1 \mathrm{~g} / \mathrm{L}$ citric acid (Merck, Taufkirchen, Germany), which is a food-grade material used as an aromatic and preservative in foods and non-alcoholic beverages [34]. Subsequently, cheese whey was placed into sterile glass containers (a total volume $200 \mathrm{~mL}$ ), and the probiotic biocatalyst was incorporated at various concentrations (A1: 0.3; A2: 0.6; A3: 1.2 g per $100 \mathrm{~mL}$ of whey beverage) using continuous stirring. For comparison reasons, whey beverages were also prepared only with the addition of Pistacia terebinthus resin (Pissa Paphos) using the following concentrations: B1: 0.3; B2: 0.6; and B3: $1.2 \mathrm{~g}$ per $100 \mathrm{~mL}$ of whey beverage. Finally, deproteinized cheese whey was used as a control sample without any further treatment (sample C). All products were stored at $4{ }^{\circ} \mathrm{C}$ for 30 days.

\subsection{Whey Beverages Microbiological Profile}

Samples of $10 \mathrm{~g}$ each of sour milk were diluted into $100 \mathrm{~mL}$ of sterile 1/4 strength Ringer's solution (LabM) and mixed in a stomacher (Bagmixer 400, Model VW, Interscience, Saint Nom, France). Subsequently, the appropriate serial dilutions were prepared by sterile Ringer's solution $\frac{1}{4}$ strength. Viable counts for yeasts and fungi, coliforms, enterobacteria, Salmonella, and staphylococci were performed in triplicate by pour plating $0.1 \mathrm{~mL}$ or $1 \mathrm{~mL}$ of appropriate dilutions on the suitable (selective) media for each species and according to instructions given by the manufacturer [35]. Specifically, yeasts and fungi were determined by plating on potato dextrose agar (PDA) (Fluka, Buchs, Switzerland) after 
incubation at $30^{\circ} \mathrm{C}$ for $72 \mathrm{~h}$. Coliforms were enumerated on violet red bile agar (LabM) after incubation at $30^{\circ} \mathrm{C}$ for $24 \mathrm{~h}$. Total enterobacteria were enumerated on violet red bile glucose agar (VRBGA) (LabM) after incubation at $37^{\circ} \mathrm{C}$ for $24 \mathrm{~h}$. Staphylococci counts were performed on Baird-Parker agar with added egg yolk tellurite medium (BP) (LabM) after incubation at $37^{\circ} \mathrm{C}$ for $48 \mathrm{~h}$, while possible counts of Staphylococcus aureus could be identified by plate counting on the first $24 \mathrm{~h}$ of incubation. Viable cells of $L$. casei were enumerated on MRS-V agar containing $1 \%$ vancomycin antibiotic (Fluka) and expressed as the percentage survival of probiotic cells during 30 days of storage $\left(4^{\circ} \mathrm{C}\right)$ [19].

\subsection{Physicochemical Analysis}

The $\mathrm{pH}$ values of whey beverages were measured using a digital $\mathrm{pH}$ meter by direct immersion of the electrode (EPI-BION SENTRON pH-System 1001, Kamerlingh-Onnesstraat, Netherlands). Titratable acidity was determined using $0.1 \mathrm{~mol} \mathrm{~L}^{-1} \mathrm{NaOH}$ (Sigma-Aldrich Ltd., St Louis, MI, USA), and phenolphthalein was used as an indicator and expressed as $\mathrm{g}$ of lactic acid per $100 \mathrm{~mL}$ of whey beverage.

Sugars (glucose, galactose, and lactose) were determined by high-performance liquid chromatography (HPLC). All samples were diluted at $1 \%(v / v)$ and filtered through a $0.2 \mathrm{~nm}$ disposable cellulose acetate filters (Chromafil), and $40 \mu \mathrm{L}$ of the filtrates were injected directly into the column. A Shimadzu HPLC system (Kyoto, Japan) equipped with a SCR-101N stainless steel column, a LC-9A pump, a CTO-10A oven at $60^{\circ} \mathrm{C}$, and a RID-6A refractive index detector was used for the analysis. Ultra-pure water obtained by a Milli-Q water purifier system (resistivity $18.2 \mathrm{M} \Omega \mathrm{cm}^{-1}$ ) with a flow rate of $0.8 \mathrm{~mL} \mathrm{~min}^{-1}$ was used as a mobile phase, and 1-butanol $(0.1 \%, v / v)$ (Sigma-Aldrich Ltd.) was used as an internal standard. Sugar concentrations were calculated using standard curves.

\subsection{Analysis of Aroma Volatiles by Solid-Phase Microextraction Gas Chromatography-Mass Spectrometry}

Selected whey beverages were analyzed after 30 days of storage $\left(\right.$ at $\left.4{ }^{\circ} \mathrm{C}\right)$ and compared with control samples (C). For solid-phase microextraction gas chromatography/mass spectrometry (SPME GC/MS) analysis, $7 \mathrm{~mL}$ of beverage samples (B2, C) were collected and mixed with $3 \mathrm{~g}$ of salt (Sigma-Aldrich Ltd., St Louis, USA) [36]. The samples were placed into a 20-mL headspace vial, which was sealed with a rubber septum and heated in a water bath for approximately $5 \mathrm{~min}$ for the temperature to be stabilized at $60^{\circ} \mathrm{C}$. Then, each sample was heated $\left(60^{\circ} \mathrm{C}\right)$ for $45 \mathrm{~min}$, while the SPME needle (bearing a 2-cm fiber, 50/30 mm DVD/Carboxen/PDMS Stable Flex Supelco, Bellefonte, state of Pennsylvania, USA) was inserted through the septum, and the fiber was exposed to the headspace. The volatiles absorbed from the SPME needle were analyzed by GC/MS (Shimadzu GC-17A, MS QP5050; Shimadzu, Kyoto, Japan with a capillary column Supelco CO Wax-10; 60 m, 0.32 mm i.d., 0.25- $\mu \mathrm{m}$ film thickness; Merck, Darmstadt, Germany) coupled with a GCMS-QP5050A mass spectrometer. Helium was used as the carrier gas (linear velocity of $1.5 \mathrm{~mL} \mathrm{~min}^{-1}$ ). The oven temperature was programmed at $35^{\circ} \mathrm{C}$ for $3 \mathrm{~min}, 5^{\circ} \mathrm{C} \mathrm{min}-1$ to $110{ }^{\circ} \mathrm{C}$, and then $10{ }^{\circ} \mathrm{C} \mathrm{min}^{-1}$ to $240{ }^{\circ} \mathrm{C}$, after which it was retained at $240{ }^{\circ} \mathrm{C}$ for $10 \mathrm{~min}$. The injector operated in a spitless mode. The injector and detector temperatures were programmed at $280{ }^{\circ} \mathrm{C}$ and $250{ }^{\circ} \mathrm{C}$, respectively. The mass spectrometer was operated in electron impact mode with the electron energy set at $70 \mathrm{eV}$.

The identification of aromatic compounds was achieved by comparison with standard compounds and data obtained from NIST107, NIST21 (www.nist.gov), and SZTERP (Shimadzu Instruction Manual) libraries. The results were expressed as the percentage of the total identified compounds [22].

\subsection{Sensory Evaluation}

Sensory evaluation was carried out by a group of 10 adult laboratory members (five men and five women) aged between 22 and 55. Whey beverages (C, A2, B2) were assessed for their sensory characteristics regarding appearance, flavor, texture, acidity, sweetness, mastic odor, cheese odor, and overall acceptability. The intensity of the studied attributes was conducted on a $0-10 \mathrm{~cm}$ unstructured linear scale (the higher the number, the greater the intensity) anchored with the words "high intensity" 
and "absence" on the right and left ends, respectively [22]. Whey beverages were evaluated on the 30 th day of storage at $4{ }^{\circ} \mathrm{C}$. Evaluations were conducted at ambient room temperature under standard fluorescent light. The samples were placed into glass containers of equivalent amounts (50 mL), coded randomly by three-digital numbers, and served $\operatorname{cool}\left(\sim 4{ }^{\circ} \mathrm{C}\right)$. Evaluators used bread and low mineral content water to neutralize and clean their mouths between sample testing. The results are presented as a star chart of the product's attributes.

\subsection{Experimental Design and Statistical Analysis}

All the experiments were performed in duplicate, all analyses were carried out in triplicate, and the results are presented as mean values \pm standard deviation. The statistical differences among treatments were estimated by analysis of variance (ANOVA). Whenever ANOVA indicated a significant difference between variables at a significance level of $5 \%(p<0.05)$, the Tukey's HSD (honest significant difference) test was carried out using the Analysis ToolPak of Microsoft ${ }^{\circledR}$ Excel $^{\circledR} 2016$ software (Microsoft, Washington, DC, USA).

\section{Results and Discussion}

\subsection{Microbiological Characteristics and Probiotics Viability}

L. casei ATCC 393 is a probiotic bacterium that has been added in many dairy products such as cheeses [22,37], fermented beverages [38], frozen desserts [19], and yogurts [39]. The selected strain has been applied either as a starter or as an adjunct probiotic culture mainly due to its health potential and its stability during manufacture and storage as well as due to its high survival rates reported under simulated gastrointestinal conditions $[19,36]$. In vitro and preliminary in vivo studies have demonstrated that $L$. casei ATCC 393 displayed several probiotic properties such as cholesterol removal in parallel with pathogens reduction and more importantly distinct adhesion in rat intestinal mucosa $[40,41]$.

As shown in Figure 1, the survival of $L$. casei reduced by $4 \%$ during 30 days of storage in the case of sample A3. This outcome may come as a result of the higher amount of incorporated resin $(1.2 \mathrm{~g}$ per $100 \mathrm{~mL}$ whey beverage) in sample A3, providing an increased terpene concentration, which may have acted against probiotic cells. On the other hand, the viability of probiotic cells increased during storage in both samples A1 and A2 (Figure 1). Specifically, samples A1 and A2 showed a 3.7\% and $8.7 \%$ increase of cell viability, respectively, by the 30th storage day. Likewise, the obtained results showed that the survival of L. casei might be promoted by using lower concentrations of the resin. Nevertheless, a sharp decrease was observed in the case of $1.2 \mathrm{~g}$ of resin per $100 \mathrm{~mL}$ of whey; thus, the survival of $L$. casei cells seems to be negatively affected after a critical P. terebinthus concentration. High survival rates of probiotic cells $\left(>6 \log \mathrm{cfu} \mathrm{mL}^{-1}\right)$ are mandatory in food products targeting to provide their beneficial effects to the consumer [20]. In addition, a more recent study showed that probiotic whey beverages may offer protection against Salmonella typhimurium infection in mice, verifying the importance of probiotic cells viability as a health factor [42]. In the present study, whey beverages enriched with $0.3 \mathrm{~g}$ (A1) and $0.6 \mathrm{~g}$ (A2) per $100 \mathrm{~mL}$ of whey were proved to be the most successful treatments regarding probiotic viability, while sample A2 showed the highest viability rates between all samples (Figure 1). In a similar approach, Ambrosio et al. highlighted that citrus terpenes showed great activity against pathogenic bacteria, without affecting beneficial bacteria [43]. As a result, citrus terpenes were reported to provide the best selective antimicrobial effect between pathogenic and beneficial bacteria [43]. Likewise, in the present study, Pistacia terebinthus resin along with its high terpene concentration provided an antimicrobial effect against possible pathogenic or spoilage microorganisms and had a minimum effect on the immobilized probiotic culture.

Samples of whey beverages were also tested for their microbial stability regarding yeast and fungi, staphylococci, enterobacteria, and coliforms as a shelf-life indicator, during a refrigerated storage period of 30 days. The control whey beverage presented significantly $(P>0.05)$ higher amounts of 
yeast and fungi $\left(1.03 \log \mathrm{cfu} \mathrm{g}^{-1}\right)$ from the first storage day, which increased significantly $(P>0.05)$ at the 30th storage day $\left(4.16 \log \mathrm{cfu} \mathrm{g}^{-1}\right)$. The accumulation of yeast and fungi in pasteurized whey may come as a result of air or facilities contamination, as they are the most frequent contaminant of food products [44]. On the contrary, no spoilage or possible pathogenic microorganisms were detected during the storage of whey beverages with the incorporated resin, either added alone (B1, B2, B3) or as an immobilized biocatalyst (A1, A2, A3). These results are in accordance with previous studies indicating that mastic resins may provide antimicrobial characteristics when incorporated within dairy products as a result of their terpene abundance [22,23]. Regarding this subject, it has been well documented that terpenes, terpenoids, and phenylpropenes are considered as the most active antimicrobial compounds when incorporated in dairy products $[23,45,46]$.

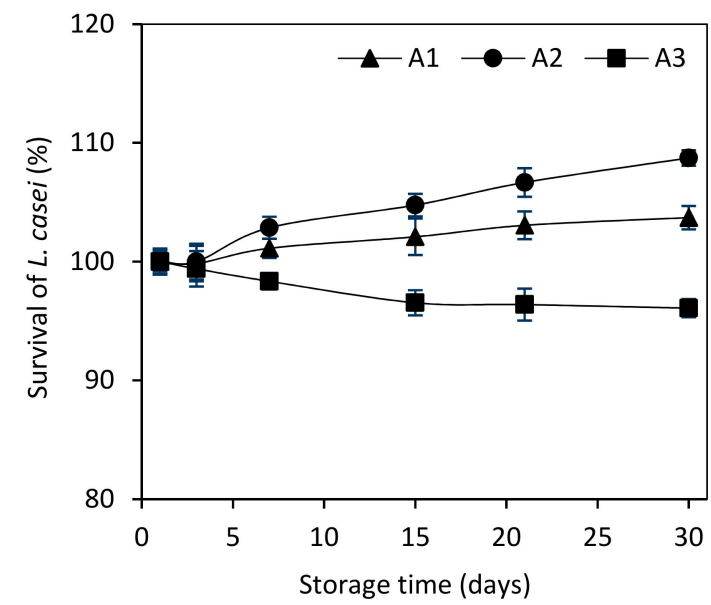

(A)

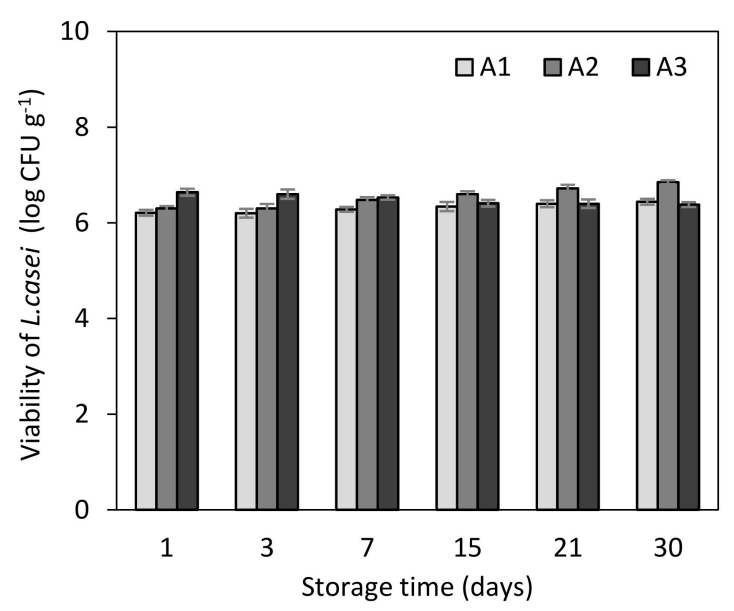

(B)

Figure 1. Viability of the immobilized probiotic cells (L. casei ATCC393 immobilized on Pistacia terebinthus resin) added at various concentrations (A1: $0.3 \mathrm{~g}, \mathrm{~A} 2: 0.6 \mathrm{~g}$, and A3: $1.2 \mathrm{~g}$ per $100 \mathrm{~mL}$ of whey) during whey beverages cold storage $\left(4^{\circ} \mathrm{C}\right)$ for 30 days (viability expressed as $(\mathbf{A}) \%$ survival and (B) $\left.\log \mathrm{cfu} \mathrm{gr}^{-1}\right)$.

\subsection{Physicochemical Characteristics of Whey Beverages}

All whey beverages were evaluated concerning their lactose, glucose, and galactose concentration, $\mathrm{pH}$ value, and total acidity, and the results are presented in Table 1. A slight increase in total acidity and a parallel $\mathrm{pH}$ decrease in whey beverages were observed in the case of the incorporated probiotic biocatalyst (A1, A2, and A3) as compared to whey beverages with only resin (B1, B2, and B3), which showed a more likely constant total acidity and $\mathrm{pH}$ value. Lactose content was slightly decreased during the storage of whey beverages containing the immobilized biocatalyst (A1 A2, and A3) due to the viable probiotic cells, which are known to consume lactose even at harsh conditions (low temperature, low $\mathrm{pH}$ ) producing lactic acid [47]. Likewise, lactose was hydrolyzed to glucose and galactose only in the case of whey beverages containing the immobilized biocatalyst. Glucose could be characterized as a preferred carbon source compared to galactose; hence, a significant decrease in glucose content was obtained during the 30 days of storage, while the amounts of galactose were higher in all cases. Glucose is an easily metabolized sugar and is mostly preferred by microorganisms as energy source [39]. Nevertheless, a slight reduction of glucose has been also observed in control beverages at the 30th day of storage, which may be explained due to yeast and fungi accumulation, as reported in Section 2.2. 
Table 1. Determination of $\mathrm{pH}$, total acidity, glucose, galactose, and lactose content of whey beverages during 30 days of refrigerated $\left(4^{\circ} \mathrm{C}\right)$ storage.

\begin{tabular}{|c|c|c|c|c|c|c|}
\hline $\begin{array}{c}\text { Whey } \\
\text { Beverage }\end{array}$ & $\begin{array}{c}\text { Storage } \\
\text { Time (Days) }\end{array}$ & $\mathrm{pH}$ & $\begin{array}{c}\text { Total } \\
\text { Acidity }{ }^{1}\end{array}$ & Glucose $^{2}$ & Galactose $^{2}$ & Lactose $^{2}$ \\
\hline \multirow{3}{*}{$\mathrm{C}$} & 1 & $3.92 \pm 0.02^{\mathrm{a}}$ & $0.6 \pm 0.04^{a}$ & $0.30 \pm 0.01^{\mathrm{a}}$ & $0.18 \pm 0.01^{\mathrm{a}}$ & $1.82 \pm 0.01^{a}$ \\
\hline & 15 & $3.93 \pm 0.02^{a}$ & $0.6 \pm 0.04^{\mathrm{a}}$ & $0.27 \pm 0.02^{\mathrm{a}}$ & $0.18 \pm 0.01^{\mathrm{a}}$ & $1.80 \pm 0.01^{a}$ \\
\hline & 30 & $4.02 \pm 0.02^{b}$ & $0.5 \pm 0.04^{b}$ & $0.22 \pm 0.01^{b}$ & $0.11 \pm 0.01^{b}$ & $1.80 \pm 0.01^{\mathrm{a}}$ \\
\hline \multirow{3}{*}{ A1 } & 1 & $3.90 \pm 0.02^{a}$ & $0.7 \pm 0.04^{\mathrm{a}}$ & $0.16 \pm 0.01^{a}$ & $0.20 \pm 0.02^{a}$ & $1.80 \pm 0.01^{a}$ \\
\hline & 15 & $3.69 \pm 0.02^{b}$ & $0.7 \pm 0.03^{a}$ & $0.13 \pm 0.01^{b}$ & $0.21 \pm 0.02^{\mathrm{a}}$ & $1.79 \pm 0.01^{\mathrm{a}}$ \\
\hline & 30 & $3.67 \pm 0.02^{b}$ & $0.7 \pm 0.03^{a}$ & $0.11 \pm 0.01^{b}$ & $0.23 \pm 0.02^{\mathrm{a}}$ & $1.70 \pm 0.01^{b}$ \\
\hline \multirow{3}{*}{ A2 } & 1 & $3.90 \pm 0.02^{a}$ & $0.7 \pm 0.04^{\mathrm{a}}$ & $0.17 \pm 0.01^{a}$ & $0.20 \pm 0.02^{a}$ & $1.78 \pm 0.01^{a}$ \\
\hline & 15 & $3.71 \pm 0.02^{b}$ & $0.7 \pm 0.03^{\mathrm{a}}$ & $0.13 \pm 0.01^{b}$ & $0.22 \pm 0.02^{\mathrm{a}}$ & $1.70 \pm 0.01^{b}$ \\
\hline & 30 & $3.64 \pm 0.02^{c}$ & $0.7 \pm 0.04^{\mathrm{a}}$ & $0.10 \pm 0.02^{b}$ & $0.21 \pm 0.02^{\mathrm{a}}$ & $1.65 \pm 0.02^{c}$ \\
\hline \multirow{3}{*}{ A3 } & 1 & $3.90 \pm 0.02^{a}$ & $0.7 \pm 0.03^{a}$ & $0.17 \pm 0.01^{a}$ & $0.25 \pm 0.02^{a}$ & $1.81 \pm 0.01^{a}$ \\
\hline & 15 & $3.71 \pm 0.02^{b}$ & $0.7 \pm 0.04^{\mathrm{a}}$ & $0.14 \pm 0.02^{b}$ & $0.23 \pm 0.02^{\mathrm{a}}$ & $1.80 \pm 0.01^{a}$ \\
\hline & 30 & $3.71 \pm 0.02^{b}$ & $0.7 \pm 0.04^{a}$ & $0.13 \pm 0.05^{b}$ & $0.24 \pm 0.02^{a}$ & $1.77 \pm 0.01^{b}$ \\
\hline \multirow{3}{*}{ B1 } & 1 & $3.93 \pm 0.02^{a}$ & $0.6 \pm 0.03^{a}$ & $0.33 \pm 0.02^{\mathrm{a}}$ & $0.18 \pm 0.01^{\mathrm{a}}$ & $1.83 \pm 0.01^{\mathrm{a}}$ \\
\hline & 15 & $3.91 \pm 0.02^{\mathrm{a}}$ & $0.6 \pm 0.04^{\mathrm{a}}$ & $0.31 \pm 0.02^{\mathrm{a}}$ & $0.18 \pm 0.02^{\mathrm{a}}$ & $1.83 \pm 0.01^{\mathrm{a}}$ \\
\hline & 30 & $3.88 \pm 0.02^{a}$ & $0.6 \pm 0.04^{a}$ & $0.32 \pm 0.02^{a}$ & $0.15 \pm 0.03^{a}$ & $1.83 \pm 0.01^{a}$ \\
\hline \multirow{3}{*}{ B2 } & 1 & $3.93 \pm 0.02^{a}$ & $0.6 \pm 0.04^{a}$ & $0.31 \pm 0.02^{a}$ & $0.17 \pm 0.01^{\mathrm{a}}$ & $1.80 \pm 0.01^{a}$ \\
\hline & 15 & $3.91 \pm 0.03^{a}$ & $0.6 \pm 0.04^{\mathrm{a}}$ & $0.32 \pm 0.02^{\mathrm{a}}$ & $0.15 \pm 0.03^{\mathrm{a}}$ & $1.80 \pm 0.01^{\mathrm{a}}$ \\
\hline & 30 & $3.90 \pm 0.02^{a}$ & $0.6 \pm 0.04^{\mathrm{a}}$ & $0.33 \pm 0.02^{a}$ & $0.15 \pm 0.02^{a}$ & $1.81 \pm 0.02^{a}$ \\
\hline \multirow{3}{*}{ B3 } & 1 & $3.94 \pm 0.02^{a}$ & $0.6 \pm 0.04^{a}$ & $0.33 \pm 0.02^{a}$ & $0.18 \pm 0.01^{\mathrm{a}}$ & $1.83 \pm 0.01^{\mathrm{a}}$ \\
\hline & 15 & $3.92 \pm 0.02^{\mathrm{a}}$ & $0.6 \pm 0.04^{\mathrm{a}}$ & $0.34 \pm 0.02^{\mathrm{a}}$ & $0.17 \pm 0.01^{\mathrm{a}}$ & $1.82 \pm 0.01^{\mathrm{a}}$ \\
\hline & 30 & $3.91 \pm 0.02^{\mathrm{a}}$ & $0.6 \pm 0.04^{\mathrm{a}}$ & $0.32 \pm 0.02^{\mathrm{a}}$ & $0.18 \pm 0.02^{\mathrm{a}}$ & $1.82 \pm 0.01^{\mathrm{a}}$ \\
\hline
\end{tabular}

${ }^{1}$ Expressed as \% lactic acid; ${ }^{2}$ Expressed as g per $100 \mathrm{~mL}$ whey beverage; Different letters (a, b, c) indicate significant differences $(p<0.05)$ among different storage days for each whey beverage.

\subsection{Effect of Pistacia Terebinthus Resin on Volatile By-Products of Functional Whey Beverages}

Terpene hydrocarbons can serve as effective flavoring ingredients providing citrus, pine, balsamic, woody, and fruity notes when detected in food matrices [48]. As it has been well documented, terpenes deriving from essential oils can serve as natural antimicrobial agents $[45,49]$ as well as effective flavoring ingredients $[48,50]$ when incorporated into food products. Whey beverages showing the optimum probiotic viability (A2) during storage $\left(4^{\circ} \mathrm{C}\right)$ were analyzed after the 30th day of production for their terpene content by SPME/GC-MS technique and compared with the respective whey beverages containing only resin (B2) and control whey beverages (C).

As expected, no terpenoid compounds were detected in control whey beverages (only traces of D-limonene and a-pinene), whereas in whey beverages containing the immobilized biocatalyst (A2) or the resin alone (B2) the analysis revealed eight and nine different monoterpenes and 10 oxygenated monoterpenes, respectively (Table 2). These results indicated that terpenoid compounds detected in whey beverages were derived from Pistacia terebinthus resin. Specifically, monoterpenes represented $\sim 85 \%$ of the total terpenes, while oxygenated monoterpenes represented $\sim 15 \%$ of the total terpenes in both cases (Figure 2). The most abundant representative of monoterpenes, as depicted in Table 2, was $\alpha$-pinene (76.5\% and $73.9 \%$ of total terpenoids) followed by $\beta$-pinene (3.6\% and $4.2 \%$ of total terpenoids) and D-limonene (1.8\% and $2.1 \%$ of total terpenoids) for the case of A2 and B2, respectively; this result was mostly expected, since these compounds are the most abundant in the essential oils of Pistacia tree species $[23,51]$. 


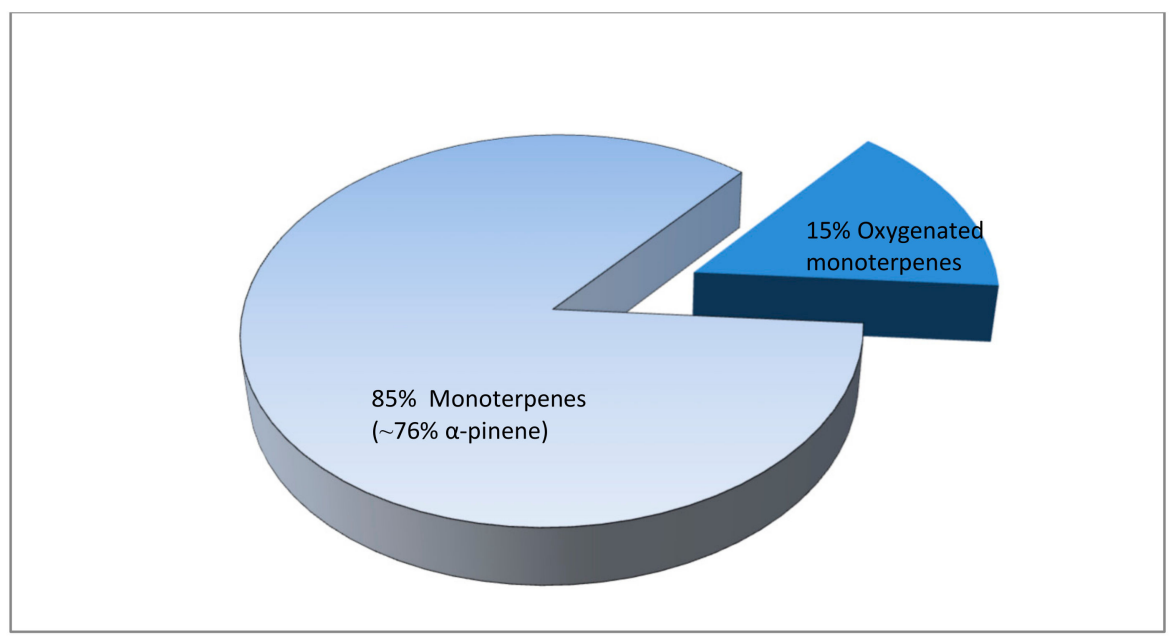

Figure 2. Diagram of terpene hydrocarbons of whey beverage (A2) presented as the percentage of each category.

Most of the detected terpenes are characterized by exceptional aromatic characteristics and can contribute to the aroma and flavor of the produced beverages by neutralizing any negative aromatic characteristics of whey caused by the occurrence of phenolic compounds or short-chain fatty acids [52,53]. Especially, monoterpenes can provide unique floral and fruity aromatic characteristics to food products due to their low threshold values [22]. For example, $\alpha$-pinene (75.6\% of total terpenoids) is an important bicyclic terpenoid that is widely used in the fragrance industry and for the synthesis of a variety of chemicals, while it is mostly known for its pine odor [54]. D-limonene ( $1.8 \%$ of total terpenoids) is reported to be responsible for a citrus mint and could be derived not only from the resin but also from whey fermentation via the probiotic culture [55]. A similar aromatic effect can be provided via other monoterpenes also; for example, linalool ( $0.8 \%$ of total terpenoids) is known for its sweet floral orange odor, while 3 -carene $(0.7 \%$ of total terpenoids) is known for its sweet lemon odor $[53,56]$.

More importantly, apart from their pleasant odor, the plethora of monoterpenes as well as some oxygenated monoterpenes has been reported to show multiple biological activities against various pathogens and provide beneficial health effects to the consumer [57]. Specifically, $\alpha$-pinene and $\beta$-pinene, which were the most abundant monoterpenes detected in whey beverages, show high antimicrobial and antioxidant effects and could provide an important health impact. For instance, according to a recent study, Pistacia atlantica essential oil provided a protective effect against ethanol-induced gastric ulcer and an antibacterial effect against Helicobacter pylori with $\alpha$-pinene being most likely the responsible agent of this biological activity [58]. Likewise, another study demonstrated that $\alpha$-pinene may pose a significant anti-Leishmania activity [59]. Additionally, camphene (1.2\% of total terpenoids), which is a bicyclic monoterpene, is considered a key compound, since it can provide various biological benefits such as anticancer, anti-inflammatory, antifungal and anti-gastric ulcer activity [60,61]. Among oxygenated monoterpenes, $\alpha$-terpineol (4.8\% of total terpenoids) was the most abundant, which presents an important antimicrobial effect against E. coli and S. aureus [46].

To conclude, terpenoid compounds are proposed to be considered not only as aromatic agents but more importantly as potential eco-friendly alternatives in food preservation targeting to prolong the shelf life of food products along with providing their beneficial health effects. In addition, the recent related studies dealing with efficient probiotic delivery [62], antioxidant activity [63], low-cost approaches to optimize sensory attributes [64], the evaluation of acceptance [65], and nutritional quality [66] point out the high commercialization potential of whey-based functional beverages. 
Table 2. Volatile compounds identified by solid-phase microextraction gas chromatography/mass spectrometry (SPME/GC-MS) in whey beverages (A2: $0.6 \mathrm{~g}$ of the immobilized biocatalyst per $100 \mathrm{~mL}$ of whey; B2: $0.6 \mathrm{~g}$ of Pistacia terebinthus resin per $100 \mathrm{~mL}$ of whey; C: control sample) after 30 days of storage (all values presented as percentage).

\begin{tabular}{|c|c|c|c|c|}
\hline Compounds & ID * & $\mathrm{C}$ & A2 & B2 \\
\hline \multicolumn{5}{|l|}{ Esters } \\
\hline ethyl acetate & RT, KI, MS & 1.4 & 0.7 & 1.3 \\
\hline ethyl butanoate & RT, KI, MS & 2.7 & 1.3 & 2.1 \\
\hline propyl butanoate & MS & $\mathrm{Nd}$ & 0.1 & 0.2 \\
\hline ethyl pentanoate & MS & $\mathrm{Nd}$ & 0.1 & 0.1 \\
\hline butyl butanoate & MS & 1.3 & 0.8 & 1.2 \\
\hline ethyl hexanoate & RT, KI, MS & 2.5 & 1.5 & 1.9 \\
\hline ethyl heptanoate & RT, MS & $\mathrm{Nd}$ & $\operatorname{Tr}$ & 0.2 \\
\hline ethyl octanoate & RT, KI, MS & 3.4 & 1.7 & 3.1 \\
\hline ethyl nonanoate & RT, MS & $\mathrm{Nd}$ & 0.1 & 0.1 \\
\hline ethyl decanoate & RT, KI, MS & 1.2 & 0.8 & 0.8 \\
\hline ethyl dodecanoate & KI, MS & 0.8 & 0.5 & 0.5 \\
\hline ethyl tetradecanoate & $\mathrm{KI}, \mathrm{MS}$ & $\mathrm{Nd}$ & 0.1 & $\mathrm{Nd}$ \\
\hline Sum esters/Sum total compounds & & 13.2 & 7.7 & 11.5 \\
\hline \multicolumn{5}{|l|}{ Organic acids } \\
\hline boutanoic acid & RT, MS & 4.1 & 2.7 & 3.3 \\
\hline hexanoic acid & RT, MS & 11.6 & 11.6 & 10.6 \\
\hline 2-methyl-butanoic acid & KI, MS & $\mathrm{Nd}$ & 0.6 & $\mathrm{Nd}$ \\
\hline 3-methyl-butanoic acid & KI, MS & $\mathrm{Nd}$ & 0.9 & 0.1 \\
\hline octanoic acid & RT, KI, MS & 13.5 & 16.2 & 10.3 \\
\hline nonanoic acid & RT, KI, MS & 2.8 & 1.5 & 2.1 \\
\hline decanoic acid & RT, KI, MS & 8.7 & 14.5 & 7.4 \\
\hline Sum acids/Sum total compounds & & 40.6 & 48.1 & 33.7 \\
\hline \multicolumn{5}{|l|}{ Alcohols } \\
\hline 2-pentanol & & $\mathrm{Nd}$ & 0.3 & $\mathrm{Nd}$ \\
\hline 2-methyl-1-butanol & RT, MS & $\mathrm{Nd}$ & 0.3 & $\mathrm{Nd}$ \\
\hline 3-methyl-1-butanol & RT, MS & 1.6 & $\mathrm{Nd}$ & $\mathrm{Nd}$ \\
\hline 2-heptanol & RT, MS & $\mathrm{Nd}$ & 0.2 & $\mathrm{Nd}$ \\
\hline 1-hexanol & RT, KI, MS & 9.6 & 2.4 & 6.6 \\
\hline 1-octen-3-ol & RT, KI, MS & 2.5 & 1.5 & 3.1 \\
\hline 1-heptanol & RT, KI, MS & 1.2 & 1.4 & $\mathrm{Nd}$ \\
\hline 2-ethyl-1-hexanol & RT, KI, MS & 1.8 & 1.3 & 1.7 \\
\hline 1-octanol & RT, KI, MS & 1.0 & 1.0 & 0.2 \\
\hline phenylethyl alcohol & RT, KI, MS & 0.9 & 2.2 & 2.4 \\
\hline Sum alcohols/Sum total compounds & & 18.7 & 10.5 & 14.0 \\
\hline \multicolumn{5}{|l|}{ Aldehydes } \\
\hline 3-methyl butanal & RT, MS & 1.6 & 1.0 & 2.3 \\
\hline hexanal & $\mathrm{RT}, \mathrm{KI}, \mathrm{MS}$ & 6.0 & 2.4 & 3.9 \\
\hline heptanal & RT, KI, MS & 2.9 & 1.7 & 3.4 \\
\hline octanal & RT, KI, MS & 1.1 & 0.9 & $\mathrm{Nd}$ \\
\hline 2-pentenal & RT, MS & $\mathrm{Nd}$ & 0.7 & $\mathrm{Nd}$ \\
\hline 2-heptenal & RT, KI, MS & $\mathrm{Nd}$ & $\mathrm{Nd}$ & 0.1 \\
\hline 2-octenal & RT, MS & 1.3 & 0.8 & 2.2 \\
\hline nonanal & RT, MS & $\mathrm{Nd}$ & 0.2 & $\mathrm{Nd}$ \\
\hline decanal & RT, KI, MS & 1.2 & 0.5 & 1.1 \\
\hline benzaldehyde & RT, KI, MS & 1.1 & 0.7 & 1.3 \\
\hline Sum aldehydes/Sum total compounds & & 15.4 & 8.9 & 14.4 \\
\hline \multicolumn{5}{|l|}{ Ketones } \\
\hline 2-butanone & $\mathrm{RT}, \mathrm{KI}, \mathrm{MS}$ & 3.7 & 4.6 & 3.1 \\
\hline 2-pentanone & RT, MS & 2.7 & 3.1 & 3.3 \\
\hline 2-heptanone & RT, MS & 1.9 & 3.3 & 2.5 \\
\hline 2-nonanone & RT, MS & 2.8 & 3.9 & 1.9 \\
\hline 2,3-butanedione & RT, KI, MS & 1.0 & 3.0 & $\mathrm{Nd}$ \\
\hline Sum ketones/Sum total compounds & & 12.1 & 17.9 & 10.7 \\
\hline
\end{tabular}


Table 2. Cont.

\begin{tabular}{|c|c|c|c|c|}
\hline Compounds & ID * & $\mathrm{C}$ & A2 & B2 \\
\hline \multicolumn{5}{|l|}{ Monoterpenes } \\
\hline a-pinene & KI, MS & $\operatorname{Tr}$ & 5.3 & 11.6 \\
\hline camphere & KI, MS & $\mathrm{Nd}$ & 0.1 & 0.2 \\
\hline$\beta$-pinene & KI, MS & $\mathrm{Nd}$ & 0.3 & 0.7 \\
\hline 3-carene & KI, MS & $\mathrm{Nd}$ & $\operatorname{Tr}$ & 0.1 \\
\hline$\beta$-myrcene & KI, MS & $\mathrm{Nd}$ & $\operatorname{Tr}$ & 0.1 \\
\hline 2-carene & KI, MS & $\mathrm{Nd}$ & $\mathrm{Nd}$ & 0.0 \\
\hline D-limonene & KI, MS & $\operatorname{Tr}$ & 0.1 & 0.3 \\
\hline Beta-phellandrene & KI, MS & $\mathrm{Nd}$ & $\operatorname{Tr}$ & 0.0 \\
\hline o-cymene & KI, MS & $\mathrm{Nd}$ & 0.1 & 0.2 \\
\hline Sum monoterpenes/Sum total & & $\operatorname{Tr}$ & 5.9 & 13.2 \\
\hline \multicolumn{5}{|l|}{ Oxygenated Monoterpenes } \\
\hline eucalyptol & $\mathrm{KI}, \mathrm{MS}$ & $\mathrm{Nd}$ & 0.1 & 0.1 \\
\hline terpinolene & KI, MS & $\mathrm{Nd}$ & 0.2 & 0.5 \\
\hline linalool & KI, MS & $\mathrm{Nd}$ & 0.1 & 0.2 \\
\hline 4-terpineol & KI, MS & $\mathrm{Nd}$ & 0.1 & 0.2 \\
\hline pinocarveol & KI, MS & $\mathrm{Nd}$ & 0.1 & 0.2 \\
\hline verbenol & KI, MS & $\mathrm{Nd}$ & $\operatorname{Tr}$ & 0.1 \\
\hline$\alpha$-terpineol & KI, MS & $\mathrm{Nd}$ & 0.3 & 0.8 \\
\hline melilotal & KI, MS & $\mathrm{Nd}$ & $\operatorname{Tr}$ & 0.1 \\
\hline myrtenol & KI, MS & $\mathrm{Nd}$ & $\operatorname{Tr}$ & 0.1 \\
\hline p-cymene-8-ol & KI, MS & $\mathrm{Nd}$ & 0.1 & 0.2 \\
\hline Sum oxyg. monoterpenes/Sum total & & $\operatorname{Tr}$ & 1.0 & 2.5 \\
\hline
\end{tabular}

* ID: Method of identification, KI: tentative identification by Kovats retention index in accordance with literature [22,23,25,37,67-71], RT: Positive identification by retention times that agrees with authentic compounds and by the mass spectra of authentic compounds generated in the laboratory, MS: tentative identification by mass spectra obtained from NIST107, NIST21, and SZTERP libraries, Nd: not detected, Tr: Traces $(<0.1 \%)$.

Other than terpenoid compounds, 44 whey-derived volatile compounds were detected: 31 compounds in beverage C, 33 compounds in beverage B2, and 42 compounds in beverage A2 (Table 2). These compounds included 12 esters, 7 acids, 10 alcohols, 10 aldehydes, and 5 ketones.

The majority of the identified compounds were acids, in all cases. The organic acids detected were as follows: butanoic, hexanoic, 2-methyl-butanoic, 3-methyl-butanoic, octanoic, nonanoic, and decanoic acid. Organic acids are important flavor compounds, with a relatively high threshold value that mainly derive by the lipolysis of milk lipids [72]. Nonanoic and decanoic acids have been previously reported in skim milk powder as responsible compounds for the sweet, fatty, and buttery-like odors, while octanoic acid has also been previously reported in milk whey concentrate [73]. Likewise, 3 methyl-butanoic acid is characterized for its "sweet-cheesy" flavor. As one can observe, the majority of organic acids were detected in A2 whey beverage, a result mostly expected as this beverage was the one containing the immobilized biocatalyst.

Aliphatic primary alcohols such as hexanol may impact a fruity, nutty note to the flavor, while branched-chain primary alcohols indicated the reduction of aldehydes, (e.g., 3-methyl-1-butanol derives from reduction of the aldehyde produced by leucine). Secondary alcohols, such as 2-pentanol and 2-heptanol, are formed by enzymatic reduction of the corresponding methyl ketones, which themselves are derived from fatty acids by oxidation [68]. 1-Octen-3-ol, which has been detected in all samples, is known for its distinctive mushroom flavor and has been detected in ultrahigh temperature sterile milk and in oxidized dairy products [73]. Phenylethanol detected in all cases belongs to the most odorous aromatic alcohols, presenting rose flower notes, and may derive from phenylalanine [72]. Nevertheless, in all cases, hexanol was the main detected alcohol, which is in agreement with previous similar studies [74].

Aldehydes are also an important group of volatile compounds responsible for the formation of the characteristic aroma profile of dairy products [75]. Aldehydes are major oxidation products of unsaturated fatty acids. Among them, hexanal (found in all samples) is considered a typical marker of the oxidative processes and is characterized by an intrinsic leafy green smell [76], while most aldehydes 
are considered contributors of the metallic flavor attributes of liquid whey [71]. 2-octenal, which was found in all samples, is characterized by a cucumber flavor, while 3-methyl-butanal (also identified in all samples) presents a cocoa malty flavor. Likewise, benzaldehyde, which was detected in all cases and is usually present in milk whey concentrate, presents bitter almond aromatic notes [68]. Still, the main aldehyde identified in all cases was hexanal, as also previously reported [74].

Regarding esters, ethyl butanoate, ethyl hexanoate, and ethyl octanoate have been detected in all samples. Their presence, even in low concentrations, has been associated with fruity and floral aromas and flavors, and esters are considered important compounds due to their ability to reduce the effect of unpleasant odors that might be caused by phenolic compounds or short-chain fatty acids [69].

Methyl-ketones have been previously reported as significant volatile organic compounds in dairy samples, with those between 5 and 13 carbon atoms (detected in all samples) contributing a flavor that resembles that of fruit [76]. For example, 2-heptanone contributes a green fruity flavor, while 2-nonanone contributes a malty fruity flavor. Methyl ketones are formed in a metabolic pathway during the fermentation with Lactobacillus strains, which are connected to the $\beta$-oxidation pathway [68]. 2,3-butanedione (diacetyl) is obtained from the condensation of two molecules of pyruvate during the valine and leucine biosynthesis pathways. Diacetyl is considered as a key odor compound for the buttery smell of the products. Its production is usually attributed to high production temperatures and/or the presence of various bacterial strains, while citrate is reported as a common substrate for its production [76]. It is worth noting that in our case, both high temperatures and citric acid are applied. Whey was obtained after myzithra type manufacture (which implies high production temperatures), while the initial $\mathrm{pH}$ of the beverages has been adjusted using citric acid. Hence, those facts justify the detection of diacetyl in the respective whey beverage samples.

\subsection{Effect of Pistacia terebinthus Resin on Sensory Characteristics of Whey Beverages}

Whey beverages (C, B2, A2) were assessed for their sensory characteristics on a $0-10$ preference scale, and the results are illustrated in Figure 3.

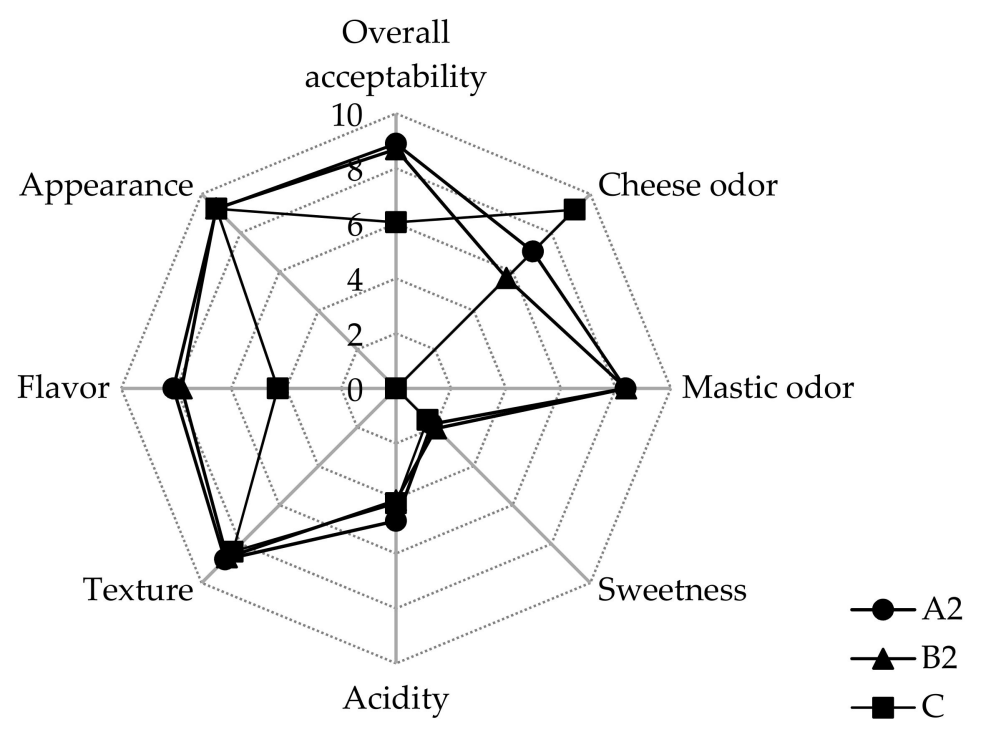

Figure 3. Sensory evaluation of whey beverages containing an immobilized biocatalyst on P. terebinthus resins (A2), P. terebinthus resins (B2), and control whey beverages at the 30 th day of storage $\left(4^{\circ} \mathrm{C}\right)$.

As one can observe, it appears that the incorporation of the resin (Pissa Paphos) either single (B2) or an immobilized biocatalyst (A2) in whey beverages affected the preference of evaluators. Beverage samples containing the resin (B2, A2) were characterized by an enhanced sweet mastic odor. At this point, it should be highlighted that evaluators could detect the taste and the aromatic character of mastic in the beverages with the incorporated resin (B2, A2), but they could not feel any difference in 
the texture of the samples. This is a very important outcome as the freeze-dried particles of the resin seemed to be homogeneously dissolved within the beverage without causing any product dysfunction. In fact, all whey beverages with the incorporated resin were characterized as cool beverages with a pleasant characteristic mastic odor. Likewise, all evaluators reported a significant flavor improvement of the beverages containing the resin (B2, A2) compared to the control sample (C). This result brings practical information to the industrial area, highlighting the valorization potential of cheese whey by-products by the incorporation or aromatic resins.

\section{Conclusions}

Pistacia terebinthus resin demonstrates a great potential, as an ingredient or support, in the development of novel nutraceutical and functional products. This study presented the development of a novel functional whey beverage, with probiotic and antimicrobial characteristics, through dairy waste valorization. The results showed that the immobilization on Pissa Pafos favored the viability of L. casei cells. In parallel, the antimicrobial properties of the resin resulted in an extended shelf life of whey beverages compared to pasteurized cheese whey, indicating the high commercialization potential of the products. Likewise, the present study highlights an alternative cheese whey valorization process, contributing toward the sustainable transition to a bioeconomy era.

Author Contributions: Conceptualization, A.T., L.B. and M.K.; Methodology, V.S., A.P. and N.K.; Investigation, V.S., A.T. and A.P.; Resources, V.S., A.T. and A.P.; Writing-Original Draft Preparation, A.T. and A.P.; Writing-Review and Editing, L.B. and N.K.; Supervision, L.B., N.K. and M.K. All authors have read and agreed to the published version of the manuscript.

Funding: This research received no external funding.

Acknowledgments: S.V. would like to thank the Greek State Scholarships Foundation (IKY) for the financial support in the frame of her PhD thesis.

Conflicts of Interest: The authors declare no conflict of interest.

\section{References}

1. Hernández-Ledesma, B.; Ramos, M.; Gómez-Ruiz, J.Á. Bioactive components of ovine and caprine cheese whey. Small Rumin. Res. 2011, 101, 196-204. [CrossRef]

2. Carvalho, F.; Prazeres, A.R.; Rivas, J. Cheese whey wastewater: Characterization and treatment. Sci. Total Environ. 2013, 445, 385-396. [CrossRef] [PubMed]

3. Prazeres, A.R.; Carvalho, F.; Rivas, J. Cheese whey management: A review. J. Environ. Manag. 2012, 110, 48-68. [CrossRef] [PubMed]

4. Yadav, J.S.S.; Yan, S.; Pilli, S.; Kumar, L.; Tyagi, R.D.; Surampalli, R.Y. Cheese whey: A potential resource to transform into bioprotein, functional/nutritional proteins and bioactive peptides. Biotechnol. Adv. 2015, 33, 756-774. [CrossRef] [PubMed]

5. Lappa, I.K.; Papadaki, A.; Kachrimanidou, V.; Terpou, A.; Koulougliotis, D.; Eriotou, E.; Kopsahelis, N. Cheese Whey Processing: Integrated Biorefinery Concepts and Emerging Food Applications. Foods 2019, 8 , 347. [CrossRef]

6. Gupta, C.; Prakash, D. Therapeutic Potential of Milk Whey. Beverages 2017, 3, 31. [CrossRef]

7. Panghal, A.; Patidar, R.; Jaglan, S.; Chhikara, N.; Khatkar, S.K.; Gat, Y.; Sindhu, N. Whey valorization: Current options and future scenario-A critical review. Nutr. Food Sci. 2018, 48, 520-535. [CrossRef]

8. Silva e Alves, A.T.; Spadoti, L.M.; Zacarchenco, P.B.; Trento, F.K.H.S. Probiotic Functional Carbonated Whey Beverages: Development and Quality Evaluation. Beverages 2018, 4, 49. [CrossRef]

9. Newbold, D.; Koppel, K. Carbonated Dairy Beverages: Challenges and Opportunities. Beverages 2018, 4, 66. [CrossRef]

10. Cortellino, G.; Rizzolo, A. Storage Stability of Novel Functional Drinks Based on Ricotta Cheese Whey and Fruit Juices. Beverages 2018, 4, 67. [CrossRef]

11. Jelen, P. 10-Whey-based functional beverages A2-Paquin, Paul. In Functional and Speciality Beverage Technology; Woodhead Publishing: Cambridge, UK, 2009; pp. 259-280. 
12. Janiaski, D.R.; Pimentel, T.C.; Cruz, A.G.; Prudencio, S.H. Strawberry-flavored yogurts and whey beverages: What is the sensory profile of the ideal product? J. Dairy Sci. 2016, 99, 5273-5283. [CrossRef] [PubMed]

13. Baccouche, A.; Ennouri, M.; Felfoul, I.; Attia, H. A physical stability study of whey-based prickly pear beverages. Food Hydrocol. 2013, 33, 234-244. [CrossRef]

14. Silveira, E.O.D.; Lopes Neto, J.H.; Silva, L.A.D.; Raposo, A.E.S.; Magnani, M.; Cardarelli, H.R. The effects of inulin combined with oligofructose and goat cheese whey on the physicochemical properties and sensory acceptance of a probiotic chocolate goat dairy beverage. LWT Food Sci. Technol. 2015, 62, 445-451. [CrossRef]

15. Guimarães, J.T.; Silva, E.K.; Costa, A.L.R.; Cunha, R.L.; Freitas, M.Q.; Meireles, M.A.A.; Cruz, A.G. Manufacturing a prebiotic whey beverage exploring the influence of degree of inulin polymerization. Food Hydrocol. 2018, 77, 787-795. [CrossRef]

16. Huang, S.; Vignolles, M.-L.; Chen, X.D.; Le Loir, Y.; Jan, G.; Schuck, P.; Jeantet, R. Spray drying of probiotics and other food-grade bacteria: A review. Trends Food Sci. Technol. 2017, 63, 1-17. [CrossRef]

17. Fiocco, D.; Longo, A.; Arena, M.P.; Russo, P.; Spano, G.; Capozzi, V. How probiotics face food stress: They get by with a little help. Crit. Rev. Food Sci. Nutr. 2019. [CrossRef]

18. Terpou, A.; Mantzourani, I.; Galanis, A.; Kanellaki, M.; Bezirtzoglou, E.; Bekatorou, A.; Koutinas, A.A.; Plessas, S. Employment of L. paracasei K5 as a Novel Potentially Probiotic Freeze-Dried Starter for Feta-Type Cheese Production. Microorganisms 2018, 7, 3. [CrossRef]

19. Terpou, A.; Papadaki, A.; Bosnea, L.; Kanellaki, M.; Kopsahelis, N. Novel frozen yogurt production fortified with sea buckthorn berries and probiotics. LWT Food Sci. Technol. 2019, 105, 242-249. [CrossRef]

20. Terpou, A.; Papadaki, A.; Lappa, I.K.; Kachrimanidou, V.; Bosnea, L.A.; Kopsahelis, N. Probiotics in Food Systems: Significance and Emerging Strategies Towards Improved Viability and Delivery of Enhanced Beneficial Value. Nutrients 2019, 11, 1591. [CrossRef]

21. Schoina, V.; Terpou, A.; Angelika-Ioanna, G.; Koutinas, A.; Kanellaki, M.; Bosnea, L. Use of Pistacia terebinthus resin as immobilization support for Lactobacillus casei cells and application in selected dairy products. J. Food Sci. Technol. 2015, 52, 5700-5708. [CrossRef]

22. Schoina, V.; Terpou, A.; Bosnea, L.; Kanellaki, M.; Nigam, P.S. Entrapment of Lactobacillus casei ATCC393 in the viscus matrix of Pistacia terebinthus resin for functional myzithra cheese manufacture. LWT Food Sci. Technol. 2018, 89, 441-448. [CrossRef]

23. Terpou, A.; Nigam, P.S.; Bosnea, L.; Kanellaki, M. Evaluation of Chios mastic gum as antimicrobial agent and matrix forming material targeting probiotic cell encapsulation for functional fermented milk production. LWT Food Sci. Technol. 2018, 97, 109-116. [CrossRef]

24. Bosnea, L.A.; Moschakis, T.; Biliaderis, C.G. Microencapsulated cells of Lactobacillus paracasei subsp. paracasei in biopolymer complex coacervates and their function in a yogurt matrix. Food Funct. 2017, 8, 554-562.

25. Kallis, M.; Sideris, K.; Kopsahelis, N.; Bosnea, L.; Kourkoutas, Y.; Terpou, A.; Kanellaki, M. Pistacia terebinthus Resin as Yeast Immobilization Support for Alcoholic Fermentation. Foods 2019, 8, 127. [CrossRef] [PubMed]

26. Rauf, A.; Patel, S.; Uddin, G.; Siddiqui, B.S.; Ahmad, B.; Muhammad, N.; Mabkhot, Y.N.; Hadda, T.B. Phytochemical, ethnomedicinal uses and pharmacological profile of genus Pistacia. Biomed. Pharmacother. 2017, 86, 393-404. [CrossRef] [PubMed]

27. Morkhade, D.M. Evaluation of gum mastic (Pistacia lentiscus) as a microencapsulating and matrix forming material for sustained drug release. Asian J. Pharm. Sci. 2017, 12, 424-432. [CrossRef]

28. Zorzan, M.; Collazuol, D.; Ribaudo, G.; Ongaro, A.; Scaroni, C.; Zagotto, G.; Armanini, D.; Barollo, S.; Galeotti, F.; Volpi, N.; et al. Biological effects and potential mechanisms of action of Pistacia lentiscus Chios mastic extract in Caco-2 cell model. J. Funct. Foods 2019, 54, 92-97. [CrossRef]

29. European Union Herbal Monograph on Pistacia lentiscus L. Resin (Mastix). Available online: https:/www.ema.europa.eu/en/documents/herbal-monograph/draft-european-union-herbal-monographpistacia-lentiscus-l-resin-mastix_en.pdf (accessed on 4 December 2019).

30. Kang, J.S.; Wanibuchi, H.; Salim, E.I.; Kinoshita, A.; Fukushima, S. Evaluation of the toxicity of mastic gum with 13 weeks dietary administration to F344 rats. Food Chem. Toxicol. 2007, 45, 494-501. [CrossRef]

31. Paraschos, S.; Magiatis, P.; Mitakou, S.; Petraki, K.; Kalliaropoulos, A.; Maragkoudakis, P.; Mentis, A.; Sgouras, D.; Skaltsounis, A.L. In vitro and in vivo activities of chios mastic gum extracts and constituents against Helicobacter pylori. Antimicrob. Agents Chemother. 2007, 51, 551-559. [CrossRef] 
32. Hadjimbei, E.; Botsaris, G.; Goulas, V.; Gekas, V. Health-Promoting Effects of Pistacia Resins: Recent Advances, Challenges, and Potential Applications in the Food Industry. Food Rev. Int. 2015, 31, 1-12. [CrossRef]

33. Bozorgi, M.; Memariani, Z.; Mobli, M.; Salehi Surmaghi, M.H.; Shams-Ardekani, M.R.; Rahimi, R. Five Pistacia species (P. vera, P. atlantica, P. terebinthus, P. khinjuk, and P. lentiscus): A Review of Their Traditional Uses, Phytochemistry, and Pharmacology. Sci. World J. 2013, 2013, 33. [CrossRef] [PubMed]

34. Favaro-Trindade, C.S.; Grosso, C.R. Microencapsulation of L. acidophilus (La-05) and B. lactis (Bb-12) and evaluation of their survival at the $\mathrm{pH}$ values of the stomach and in bile. J. Microencapsul. 2002, 19, 485-494.

35. Terpou, A.; Bosnea, L.; Kanellaki, M.; Plessas, S.; Bekatorou, A.; Bezirtzoglou, E.; Koutinas, A.A. Growth Capacity of a Novel Potential Probiotic Lactobacillus paracasei K5 Strain Incorporated in Industrial White Brined Cheese as an Adjunct Culture. J. Food Sci. 2018, 83, 723-731. [CrossRef] [PubMed]

36. Terpou, A.; Bekatorou, A.; Kanellaki, M.; Koutinas, A.A.; Nigam, P. Enhanced probiotic viability and aromatic profile of yogurts produced using wheat bran (Triticum aestivum) as cell immobilization carrier. Process. Biochem. 2017, 55, 1-10. [CrossRef]

37. Terpou, A.; Gialleli, A.-I.; Bosnea, L.; Kanellaki, M.; Koutinas, A.A.; Castro, G.R. Novel cheese production by incorporation of sea buckthorn berries (Hippophae rhamnoides L.) supported probiotic cells. LWT Food Sci. Technol. 2017, 79, 616-624. [CrossRef]

38. Terpou, A.; Bosnea, L.; Kanellaki, M. Effect of Mastic Gum (Pistacia Lentiscus Via Chia) as a Probiotic Cell Encapsulation Carrier for Functional Whey Beverage Production. SCIOL Biomed. 2017, 1, 1-10.

39. Bosnea, L.A.; Kopsahelis, N.; Kokkali, V.; Terpou, A.; Kanellaki, M. Production of a novel probiotic yogurt by incorporation of $L$. casei enriched fresh apple pieces, dried raisins and wheat grains. Food Bioprod. Process. 2017, 102, 62-71. [CrossRef]

40. Saxami, G.; Ypsilantis, P.; Sidira, M.; Simopoulos, C.; Kourkoutas, Y.; Galanis, A. Distinct adhesion of probiotic strain Lactobacillus casei ATCC 393 to rat intestinal mucosa. Anaerobe 2012, 18, 417-420. [CrossRef]

41. Lye, H.-S.; Rahmat-Ali, G.R.; Liong, M.-T. Mechanisms of cholesterol removal by lactobacilli under conditions that mimic the human gastrointestinal tract. Int. Dairy J. 2010, 20, 169-175. [CrossRef]

42. Cordeiro, M.A.; Souza, E.L.S.; Arantes, R.M.E.; Balthazar, C.F.; Guimarães, J.T.; Scudino, H.; Silva, H.L.A.; Rocha, R.S.; Freitas, M.Q.; Esmerino, E.A.; et al. Fermented whey dairy beverage offers protection against Salmonella enterica ssp. enterica serovar Typhimurium infection in mice. J. Dairy Sci. 2019, 102, 6756-6765. [CrossRef]

43. Ambrosio, C.M.S.; de Alencar, S.M.; de Sousa, R.L.M.; Moreno, A.M.; Da Gloria, E.M. Antimicrobial activity of several essential oils on pathogenic and beneficial bacteria. Ind. Crops Prod. 2017, 97, 128-136. [CrossRef]

44. Hernández, A.; Pérez-Nevado, F.; Ruiz-Moyano, S.; Serradilla, M.J.; Villalobos, M.C.; Martín, A.; Córdoba, M.G. Spoilage yeasts: What are the sources of contamination of foods and beverages? Int. J. Food Microbiol. 2018, 286, 98-110. [CrossRef] [PubMed]

45. Khorshidian, N.; Yousefi, M.; Khanniri, E.; Mortazavian, A.M. Potential application of essential oils as antimicrobial preservatives in cheese. Innov. Food Sci. Emerg. Technol. 2018, 45, 62-72. [CrossRef]

46. Badawy, M.E.I.; Marei, G.I.K.; Rabea, E.I.; Taktak, N.E.M. Antimicrobial and antioxidant activities of hydrocarbon and oxygenated monoterpenes against some foodborne pathogens through in vitro and in silico studies. Pesticide Biochem. Physiol. 2019, 158, 185-200. [CrossRef]

47. Mantzourani, I.; Terpou, A.; Alexopoulos, A.; Kimbaris, A.; Bezirtzoglou, E.; Koutinas, A.A.; Plessas, S. Production of a Potentially Synbiotic Pomegranate Beverage by Fermentation with Lactobacillus plantarum ATCC 14917 Adsorbed on a Prebiotic Carrier. Appl. Biochem. Biotechnol. 2019. [CrossRef]

48. Adams, T.B.; Gavin, C.L.; McGowen, M.M.; Waddell, W.J.; Cohen, S.M.; Feron, V.J.; Marnett, L.J.; Munro, I.C.; Portoghese, P.S.; Rietjens, I.M.C.M.; et al. The FEMA GRAS assessment of aliphatic and aromatic terpene hydrocarbons used as flavor ingredients. Food Chem. Toxicol. 2011, 49, 2471-2494. [CrossRef]

49. Rodríguez-López, M.I.; Mercader-Ros, M.T.; Pellicer, J.A.; Gómez-López, V.M.; Martínez-Romero, D.; Núñez-Delicado, E.; Gabaldón, J.A. Evaluation of monoterpene-cyclodextrin complexes as bacterial growth effective hurdles. Food Control 2019. [CrossRef]

50. Ameh, S.J.; Obodozie-Ofoegbu, O. Chapter 11-Essential Oils as Flavors in Carbonated Cola and Citrus Soft Drinks. In Essential Oils in Food Preservation, Flavor and Safety; Preedy, V.R., Ed.; Academic Press: Cambridge, MA, USA, 2016; pp. 111-121. 
51. Duru, M.E.; Cakir, A.; Kordali, S.; Zengin, H.; Harmandar, M.; Izumi, S.; Hirata, T. Chemical composition and antifungal properties of essential oils of three Pistacia species. Fitoterapia 2003, 74, 170-176. [CrossRef]

52. Fink, J.K. 12-Terpene Resins. In Reactive Polymers: Fundamentals and Applications, 3rd ed.; Fink, J.K., Ed.; William Andrew Publishing: Norwich, NY, USA, 2018; pp. 403-415.

53. Curioni, P.M.G.; Bosset, J.O. Key odorants in various cheese types as determined by gas chromatography-olfactometry. Int. Dairy J. 2002, 12, 959-984. [CrossRef]

54. Sun, L.; Liao, D.; Yang, Z.; Chen, X.; Tong, Z. Measurement and correlation of (vapor+liquid) equilibrium data for $\{\alpha$-pinene+p-cymene+(S)-(-)-limonene $\}$ ternary system at atmospheric pressure. J. Chem. Thermodynam. 2013, 58, 416-421. [CrossRef]

55. Risner, D.; Tomasino, E.; Hughes, P.; Meunier-Goddik, L. Volatile aroma composition of distillates produced from fermented sweet and acid whey. J. Dairy Sci. 2019, 102, 202-210. [CrossRef] [PubMed]

56. Vichi, S.; Riu-Aumatell, M.; Mora-Pons, M.; Guadayol, J.M.; Buxaderas, S.; López-Tamames, E. HS-SPME coupled to GC/MS for quality control of Juniperus communis L. berries used for gin aromatization. Food Chem. 2007, 105, 1748-1754. [CrossRef]

57. Petrović, J.; Stojković, D.; Soković, M. Terpene core in selected aromatic and edible plants: Natural health improving agents. In Advances in Food and Nutrition Research; Academic Press: Cambridge, MA, USA, 2019; Volume 90, pp. 423-451.

58. Memariani, Z.; Sharifzadeh, M.; Bozorgi, M.; Hajimahmoodi, M.; Farzaei, M.H.; Gholami, M.; Siavoshi, F.; Saniee, P. Protective effect of essential oil of Pistacia atlantica Desf. on peptic ulcer: Role of $\alpha$-pinene. J. Tradit. Chin. Med. 2017, 37, 57-63. [CrossRef]

59. Rodrigues, K.A.d.F.; Amorim, L.V.; Dias, C.N.; Moraes, D.F.C.; Carneiro, S.M.P.; Carvalho, F.A.D.A. Syzygium cumini (L.) Skeels essential oil and its major constituent $\alpha$-pinene exhibit anti-Leishmania activity through immunomodulation in vitro. J. Ethnopharmacol. 2015, 160, 32-40. [CrossRef]

60. Ebmeyer, F. Theoretical investigations towards an understanding of the $\alpha$-pinene/camphene rearrangement. J. Molec. Struct. Theochem. 2002, 582, 251-255. [CrossRef]

61. Girola, N.; Figueiredo, C.R.; Farias, C.F.; Azevedo, R.A.; Ferreira, A.K.; Teixeira, S.F.; Capello, T.M.; Martins, E.G.A.; Matsuo, A.L.; Travassos, L.R.; et al. Camphene isolated from essential oil of Piper cernuum (Piperaceae) induces intrinsic apoptosis in melanoma cells and displays antitumor activity in vivo. Biochem. Biophys. Res. Com. 2015, 467, 928-934. [CrossRef]

62. Fenster, K.; Freeburg, B.; Hollard, C.; Wong, C.; Rønhave Laursen, R.; Ouwehand, A.C. The Production and Delivery of Probiotics: A Review of a Practical Approach. Microorganisms 2019, 7, 83. [CrossRef]

63. Mantzourani, I.; Kazakos, S.; Terpou, A.; Mallouchos, A.; Kimbaris, A.; Alexopoulos, A.; Bezirtzoglou, E.; Plessas, S. Assessment of Volatile Compounds Evolution, Antioxidant Activity, and Total Phenolics Content during Cold Storage of Pomegranate Beverage Fermented by Lactobacillus paracasei K5. Fermentation 2018, 4 , 95. [CrossRef]

64. Capozzi, V.; Yener, S.; Khomenko, I.; Farneti, B.; Cappellin, L.; Gasperi, F.; Scampicchio, M.; Biasioli, F. PTR-ToF-MS Coupled with an Automated Sampling System and Tailored Data Analysis for Food Studies: Bioprocess Monitoring, Screening and Nose-space Analysis. J. Vis. Exp. 2017, 23, 54075. [CrossRef]

65. Aderinola, T.A. Nutritional, Antioxidant and Quality Acceptability of Smoothies Supplemented with Moringa oleifera Leaves. Beverages 2018, 4, 104. [CrossRef]

66. Roselló-Soto, E.; Garcia, C.; Fessard, A.; Barba, F.J.; Munekata, P.E.S.; Lorenzo, J.M.; Remize, F. Nutritional and Microbiological Quality of Tiger Nut Tubers (Cyperus esculentus), Derived Plant-Based and Lactic Fermented Beverages. Fermentation 2018, 5, 3. [CrossRef]

67. Mallouchos, A.; Paul, L.; Argyro, B.; Koutinas, A.; Komaitis, M. Ambient and low temperature winemaking by immobilized cells on brewer's spent grains: Effect on volatile composition. Food Chem. 2007, 104, 918-927. [CrossRef]

68. Kopsahelis, N.; Panas, P.; Kourkoutas, Y.; Koutinas, A.A. Evaluation of thermally-dried immobilized cells of Lactobacillus delbrueckii subsp. bulgaricus on apple pieces as a potent starter culture. J. Agri. Food Chem. 2007, $55,9829-9836$.

69. Terpou, A.; Gialleli, A.; Bekatorou, A.; Dimitrellou, D.; Ganatsios, V.; Barouni, E.; Koutinas, A.A.; Kanellaki, M. Sour milk production by wheat bran supported probiotic biocatalyst as starter culture. Food Bioprod. Process. 2017, 101, 184-192. [CrossRef] 
70. Dan, T.; Ren, W.; Liu, Y.; Tian, J.; Chen, H.; Li, T.; Liu, W. Volatile Flavor Compounds Profile and Fermentation Characteristics of Milk Fermented by Lactobacillus delbrueckii subsb. bulgaricus. Front. Microbiol. 2019, 10, 2183. [CrossRef]

71. Karagul-Yuceer, Y.; Drake, M.A.; Cadwallader, K.R. Aroma-active Components of Liquid Cheddar Whey. J. Food Sci. 2003, 68, 1215-1219. [CrossRef]

72. Lee, C.W.; Richard, J. Catabolism of L-phenylalanine by some microorganisms of cheese origin. J. Dairy Res. 1984, 51, 461-469. [CrossRef]

73. Quach, M.L.; Chen, X.D.; Stevenson, R.J. Headspace sampling of whey protein concentrate solutions using solid-phase microextraction. Food Res. Int. 1999, 31, 371-379. [CrossRef]

74. Bergamaschi, M.; Bittante, G. From milk to cheese: Evolution of flavor fingerprint of milk, cream, curd, whey, ricotta, scotta, and ripened cheese obtained during summer Alpine pasture. J. Dairy Sci. 2018, 101, 3918-3934. [CrossRef]

75. Dimitrellou, D.; Kandylis, P.; Levićc, S.; Petrovićc, T.; Ivanovićd, S.; Nedovićc, V.; Kourkoutas, Y. Encapsulation of Lactobacillus casei ATCC 393 in alginate capsules for probiotic fermented milk production. LWT Food Sci. Technol. 2019, 116, 108501. [CrossRef]

76. Sattin, E.; Andreani, N.A.; Carraro, L.; Lucchini, R.; Fasolato, L.; Telatin, A.; Balzan, S.; Novelli, E.; Simionati, B.; Cardazzo, B. A Multi-Omics Approach to Evaluate the Quality of Milk Whey Used in Ricotta Cheese Production. Front. Microbiol. 2016, 7, 1272. [CrossRef] [PubMed]

(C) 2019 by the authors. Licensee MDPI, Basel, Switzerland. This article is an open access article distributed under the terms and conditions of the Creative Commons Attribution (CC BY) license (http://creativecommons.org/licenses/by/4.0/). 